\title{
Analysis of Maugham's Views on the Female-Based on the Female Images in His Works
}

\author{
Jinling Xia ${ }^{a}$, Huijiao Wang ${ }^{b}$ \\ School of Foreign Language, Wuhan Technology and Business University, Wuhan 430065, China \\ a517504104@qq.com, b65619240@qq.com
}

Keywords: The uglified female images, Maugham's views on the female

\begin{abstract}
In Maugham's works, there are numerous nagative female images, and the plesant ones are difficult to find. This is not the reflection of real female images in the society. Why does Maugham have passive attitudes towards women and create so many twisted feamle images? The paper analyzes the reasons. Maugham's traumatic psychology about the female is caused by his personal traumatic experience and Men’s collective traumatic experience.
\end{abstract}

\section{Introduction}

William Somerset Maugham (1874-1965) is a popular and productive writer. He wins extensive acclaim for his literary achievement. Maugham deserves special praise for his insight into human's nature and vivid depiction of characters. In his works, he creates numerous negative female images. Maugham's intention of uglifying the female images is quite obvious. To our fun, we can even find his favorite female character in the novel of Cakes and Ale is also depicted as a dissolute woman, although Maugham intends to praise her. No wonder some researchers claim Maugham's inclination of anti-woman. ${ }^{[1]}$ Why does Maugham incline to uglify the female images, but not create the pleasant ones? After all, it is the fact that most of women in reality are lovely and sweet. The paper tries to shed light on this problem.

\section{The uglified female images}

Generally, all the unfavorable female images in Maugham's works can be classified into three types: dissolute women, hypocritical women and materialistic women.

\subsection{Dissolute women}

Maugham likes to create dissolute women most under his pen. That's also the reason why we often see the subject of adultery or betrayed love in his works. He has a fixed pattern about love stories: male characters love female characters heart and soul. However, female characters are immoral and betray love or marriages, and they have affairs with other men for various reasons. When the affairs are exposed, the tragedies occur. Maugham inclines to put much blame on women for tragedies. He thinks women are the root of the sin, and they use sexual desire to make men blind and crazy. They take advantage of immoral sexual relationships to achieve what they want, and thus lead to disasters to love and marriages.

Of Human Bondage is a Maugham's masterpiece. In this novel, a dissolute woman is vividly described, she is Mildred Rogers. In fact, this type of female images is not just limited in one novel. We can find the similar type in Maugham's other novels, such as Liza in his first published novel Liza of Lambeth, Kitty in the novel The Painted Veil, Rose in the novel Cakes and Ale...The common feature for these female characters is that they are not loyal to love or marriages, lacking moral discipline or ignoring legal restraint for their behavior, so they often bring disasters to love and marriages. To such type of women, Maugham shows no pity to them, and criticizes them severely for their behavior. 


\subsection{Hypocritical women}

In all the female images, another obvious type is hypocritical women. In Maugham's eyes, these women are very false. They like to wear a mask in life. They design to make a nice impression upon others, while they tend to forget their true identities and nature. That is, sometimes what you see is totally different from what they are, just as Maugham put in the novel The Moon and Six Pence: "I had not yet learnt how contradictory is human nature; I did not know how much pose there is in the sincere, how much baseness in the noble." ${ }^{[2]}$ This description fully shows that women's appearance can be deceiving. They may look pleasant at first, but with further contact, their nature will be revealed. We can find many such images in his works, such as Julia Lambert in Theatre, the heroine of the short story named Luncheon, as well as Isabel in The Razor's Edge...

\subsection{Materialistic women}

There is another type of women existing in Maugham's writing, that is, materialistic women. This type of women has shortcomings as the previous two types: dissolute, fickle, hypocritical, and false. However, they have another annoying shortcoming: they are addicted to wealth, social status or different forms of material comforts. In order to achieve what they want, they can sacrifice everything including true love and marriage, even marriage becomes a deal for them, as a tool to get what they want. For this type of women, they have a clear aim that they must obtain wealth and comfort. We can find many such women in Maugham's writing, such as Isabel in The Razor's Edge, Lisette and Mrs Ramsay in his short stories...

\section{Analysis of Maugham's views on the female}

Maugham, as a writer, manifests clearly his negative and radical attitudes towards women in his writing. In fact, it is not out of artistic creation. What are the real causes for this phenomenon? According to trauma theory, those who experience traumatic events will suffer from traumatic symptoms, such as intense fear, sense of distrust etc. However, "Reactions to traumatic events vary considerably, ranging from relatively mild, creating minor disruptions in the person's life, to severe and debilitating." [3] Based on trauma theory, Maugham's traumatic psychology about women has a lot to with his frustrating life experience.

\subsection{Personal traumatic experience}

Maugham went through a miserable change in his childhood. Before the age of 8, the happy memory of childhood was the most unforgettable one for him. Maugham had three elder brothers who all went to school in England when he was only three. So all his mother's most selfless love was given to him, which later became the happiest time in his life. Unfortunately this exclusive love only lasted eight years when his mother died in 1882, six days after Maugham's eighth birthday. Two years later, his father died of stomach cancer. Maugham suddenly became an orphan at the age of ten. From his loving mother Maugham got a short period of unselfish love and lost it later, which became his most beautiful as well as heart-broken memory.

"Bereavement - the response to loss - has long been seen as one of the most stressful of life's experiences, leading to distress and the complex affects referred to as grief. " ${ }^{[2]}$ No doubt, his mother's death leaves a deep scar in his spirit. It gives Maugham a heavy blow and lifelong torture, and he can not get it over for all his life, which undoubtedly has a profound negative impact on his whole life. In his eyes, women, however kind they may be to you, they can not be selfless to you as the dearest mother. Later in his life, he achieves great fame and high social status, which creates more opportunities for him to make acquaintance with females, but actually he never gets real close to them, because he doesn't believe there is a good woman like his mother in the world. So manifested in his works, it is difficult to find pleasant female images.

Apart from the early death of his mother, Maugham's failure in puppy love and marriage does a lot of profound harm to him, which directly contributes to his pessimistic and radical attitude towards women.

In Maugham's life, there are two important women who are closely associated with his life. The first one is his love Sue Jones. In about 1960, Maugham came to a party and got off with Sue Jones. 
They fell in love with each other and very soon they developed love relationship. Maugham was quite serious about the relationship with Sue Jones. Although she was casual in sexual relation, Maugham didn't care and wanted to marry her. Sue Jones was the only woman Maugham proposed to, but she turned down the proposal. Maugham found later Sue Jones was pregnant and would marry another gentleman. His puppy love suffered a crushing defeat, which shattered his trust in women.

Another important woman was Maugham's wife Celia. Celia was obsessed with Maugham for his talent when they had first met each other. Of course Maugham also had very nice impression upon her. He thought Celia would be a good wife, obedient and submissive, supporting his career. Their daughter was born two years prior to their marriage. In order to give their daughter a legitimate identity, they got married. Unfortunately, happy days did not last long. The peace of life became illusory. Maugham began to feel unendurable with her, realizing that their marriage was totally a failure. They began to have endless quarrel. The seeds of hatred were sowed in their marriage, and it gradually grew into more constant arguments. In the opinion of Maugham, Celia was only a disgusting woman who framed him into the cage of marriage, draining all his financial resources and exploiting his emotions. Finally their relationship fell apart and the marriage came to an end. Since then never a moment in his life did Maugham stop his hatred to her. Once he had a chance, he would speak ill to attack her. To vent his hatred and disgust to Celia, Maugham launched a violent attack against women in the novel of The Moon and Six pence. He used Celia as a model to shape a figure Mrs. Strickland, and vividly exposed her hypocritical and ugly nature.

No doubt, Maugham's loss of maternal love and his failure in puppy love and marriage do great harm to him. The pains and traumas were etched in his soul. The painful experience gradually shapes his negative and derogatory outlook on the female. Of course, as a writer, he shifts his emotion into his writing.

\subsection{Men's collective traumatic experience}

Men's collective traumatic experience is another important reason to account for Maugham's negative views on the female. In Maugham's time, people underwent dramatic political and economic renovations. With the breakthrough and development of science and technology as well as the emergence of different philosophic thinking, all led to tremendous changes in people's life in different aspects, including the feminist movement. In 1918, women got the right to vote, which indicated the rapid changes of the traditionally social and moral restrictions placed on women. In 1920s, along with the rapid development of industry, more and more women went out of houses to enter into the workforce. Especially during the war time, large amounts of women went to the front and filled job vacancies. From then, women were more conscious of their same ability as the men to do the jobs which were provided only to men previously. They came to realize that women could hold up half the sky and they also had productivity and a variety of possibilities. With more and more job opportunities, a number of female social groups increased rapidly. The economic independence aroused their desire of gaining a position in politics. So the first climax of western feminist movement appeared during 1920s to 1930s. With more independence in economy and the right to vote in politics, women's value and moral standards changed correspondingly. They demanded equal rights to men and chose to assert their equality in many ways. They began to have unique perception in the matter of love and marriage. They broke the traditional female images. They were not willing to be the emblems of the typical Victorian "angel in the house" and no longer obedient servants of the husbands. They refused to be confined into the family. They began to pursue their individual distinctness and selfhood in love and marriage. They were not willing to sacrifice themselves to satisfy the need of men, because they no longer relied on men. They enjoyed the independence and rights to decide everything in family. In a word, they became new women.

With women's increasing self-consciousness and radical behavior, men stepped into a restless and anxious period. They began to realize that their dominant position was gradually shaken, and men's authority retreated from the center to edge. As a man, of course, patriarchal culture was deeply rooted in Maugham's mind. Since the birth, he knew in Bible that Eve is made from one of Adam's ribs. He took men's dominance over women for granted and regarded that women were subject to men. However, all the realization experienced complete subversion. Men were not strong and powerful 
enough in front of women and they felt difficult to deal with women. Maugham was no exception. Being a realistic writer, Maugham shifts his trauma into his works and he creates many disgusting female images. In this way, he releases his hatred and disgust to women, which implies his resistance to the declining patriarchal culture.

\section{Conclusion}

Maugham inclines to create all sorts of twisted female images in his writing. It is quite obvious that he has passive views on the female. From the analysis above, it can be found that his negative attitudes are caused by more than one reason. If we know Maugham's life experience thoroughly, we can have better understanding about his literary creation.

\section{Acknowledgement}

This paper is the phase achievement of the guidance program of humanities and social science project in Hubei province (15G153).

Corresponding author: Xia Jinling, Wuhan Technology and Business University, Public English Department, Wuhan 430065, China

\section{References}

[1] Wang Dongjing, On Maugham's Inclination of Anti-woman [J], Journal of Shenyang Normal University (Social Science), 1999(3):73-75

[2] Maugham a, William Somerset. The Moon and Six Pence[M]. Knopf Doubleday Publishing Group Vintage Classics, 2000:31

[3] Wainrib, Barbara Rubin. Healing Crisis and Trauma with Mind, Body, and Spirit[M]. NewYork: Springer Publishing Company, Inc. 2006:12 